\begin{tabular}{|c|c|c|c|c|}
\hline $\begin{array}{c}\text { Jurnal Penelitian \& } \\
\text { PPM }\end{array}$ & ISSN: 2442-448X & Vol 4, No: 2 & Hal: $129-389$ & Juli 2017 \\
\hline
\end{tabular}

\title{
PENGEMBANGAN USAHA TAPE KETAN SEBAGAI PRODUK UNGGULAN DITINJAU DARI PERSPEKTIF COMMUNITY DEVELOPMENT
}

\author{
OLEH : \\ NANDANG MULYANA, ARUM SINTIA, ISHARTONO, RISNA RESNAWATY
}

1. Pusat Studi Kewirausahaan Sosial, CSR \& Pengembangan Masyarakat FISIP - Universitas Padjadjaran
2. Program Studi Sarjana (S-1) Ilmu Kesejahteraan Sosial FISIP - Universitas Padjadjaran
3. Pusat Studi Kewirausahaan Sosial, CSR \& Pengembangan Masyarakat FISIP - Universitas Padjadjaran
4. Pusat Studi Kewirausahaan Sosial, CSR \& Pengembangan Masyarakat FISIP - Universitas Padjadjaran

\begin{abstract}
$\underline{\text { Abstrak }}$
Setiap daerah mempunyai potensi yang dapat dikembangkan menjadi produk unggulan dari darah tersebut. Produk-produk unggulan tersebut harus terus dikembangan sehingga akan menjadi besar. Pengembangan produk unggulan ini tentunya akan mendukung pengemabngan ekonomi local dari daerah yang bersangkutan. Pengembangan ekonomi local juga akan mendukung masyarakat yang bersangkutan berkembang.

Pengembangan ekonomi local yang bertumpu pada produk unggulan tidak dapat dilakukan oleh pengusaha saja. Perlu adanya dukungan dari pemerintah maupun stakeholders lain yang bergerak dalam pengembangan ekonomi local. Dukungan pemerintah tentunya diperlukan dengan membuat kebijakan yang mendukung pengembangan produk unggulan. Sementara itu stakeholders lainnya membantu para pengusaha dalam mengembangkan produknya sehingga dapat berkembangan dan dikenal diluar daera.
\end{abstract}

Kata kunci : produk unggulan, pengembangan ekonomi local

\section{Pendahuluan}

Setiap daerah pada umumnya mempunyai potensi yang dapat dikembangkan menjadi suatu unggulan dari daerah yang bersangkutan. Keberadaan potensi dari suatu daerah tersebut dapat berupa potensi sumber daya alam, sumber daya manusia, sumber sejarah,maupun geografis. Semua potensi yang dimiliki oleh suatu daerah dapat dikembangkan yang selanjutnya dapat membantu masyarakat yang bersangkutan untuk lebih maju.
Pengembangan potensi yang dimiliki oleh suatu daerah tentunya akan berhubungan dengan pengembangan ekonomi masyarakat yang ada dalam daerah yang bersangkutan. Hal ini dikarenakan pemanfaatan potensi yang dimiliki akan berdampak pada kehidupan ekonomi masyarakat. Salah satu daerah yang mempunyai produk unggulan yang didasarkan pada potensi yang dimilikinya adalah Kabupaten Kuningan. Di Kabupaten Kuningan banyak potensi makanan yang menjadi ciri 
khas. Salah satu ciri khas makan dari Kabupaten Kuningan adalah tape.

Usaha produksi tape ketan di Kabupaten Kuningan tersebar di tiga kecamatan yaitu Kecamatan Cibeureum, Kecamatan Sindangagung dan Kecamatan Cigugur. Produksi tape ketan terbanyak yaitu terdapat di Desa Tarikolot. Hingga akhir tahun 1970-an usaha pembuatan tape ketan belum menjadi usaha tetap bagi warga Tarikolot. Meskipun makanan ini lazim dihidangkan pada hari Lebaran atau hajatan, para pembuatnya belum menjadikannya sebagai komoditas yang bernilai ekonomi tinggi dan menjadi pekerjaan tetap. Keterampilan membuat tape ketan tetap hanya menjadi ketrampilan tambahan sebagaimana masyarakat memperlakukan keterampilan membuat berbagai jajanan desa untuk berbagai keperluan. Akan tetapi, pada tahun 1980-an ada satu atau dua penduduk Tarikolot yang membuat tape ketan untuk kepentingan komersial secara terbatas, terutama menjelang Lebaran. Diperkirakan pada dekade itulah pembuatan tape ketan mulai menjadi usaha rumahan tidak tetap di Tarikolot dan Cibeureum. Sebab saat itu, setiap menjelang Lebaran, banyak orang dari luar Kuningan mendatangi dua desa ini untuk membeli tape ketan.

Tape Kuningan berbeda jika dibandingkan dengan tape sejenis dari daerah lainnya. Dilihat dari segi tampilan sudah membedakan antara tape Kuningan dengan tape dari dasrah lain. Tape Kuningan dibungkus menggunakan daun jambu air. Hal ini berbeda dengan tape dari daerah lain yang menggunakan daun pisang. Dari segi pembuatan juga memperlihatkan perbedaan. Tape Kuningan dalam proses pembuatannya menggunakan daun katuk yang berguna untuk memberikan warna hijau pada tape. Selain daun katuk juga berguna agar tape tidak terlalu banyak air.

Pada umumya orang-orang yang datang untuk mencari tape ketan itu ialah warga Jakarta dan Bandung yang sedang melakukan perjalanan ke Cirebon, Kuningan, atau Majalengka. Pembeli rela antre untuk sekadar mendapatkan tape ketan untuk dibawa pulang sebagai buah tangan. Sementara penduduk Kuningan juga kerap membawa tape ketan sebagai oleh-oleh kebanggaan ketika mereka berpergian ke daerah lain.

Kesohoran tape ketan sebagai oleholeh menjadikan tape ketan sebagai salah satu produk unggulan Kabupaten Kuningan. Peranan industri kecil seperti usaha tape ketan ini dalam perekonomian Indonesia dirasakan sangat penting terutama dalam aspek-aspek seperti kesempatan kerja, pemerataan pendapatan, pembangunan ekonomi di pedesaan dan lain-lain. Usaha untuk mengembangkan industri kecil dan industri rumah tangga di daerah merupakan langkah yang tepat sebagai salah satu instrumen kebijakan pemerintah untuk menanggulangi masalah-masalah ekonomi dan sosial yang dihadapi Indonesia saat ini. Perannya dalam mendorong laju pertumbuhan ekonomi dan penyerapan tenaga kerja mampu menjadi langkah awal bagi upaya pemerintah menggerakkan sektor produksi di berbagai lapangan usaha.

\section{Tinjauan Konseptual}

\section{a. Pengembangan Ekonomi Lokal}

Pengembangan ekonomi lokal menurut Blakely dan Bradshaw adalah proses dimana pemerintah lokal dan organisasi masyarakat terlibat untuk mendorong, merangsang, memelihara aktivitas usaha untuk menciptakan lapangan pekerjaan. Sedangkan menurut World Bank (2001) adalah proses dimana para pelaku pembangunan bekerja kolektif dengan mitra dari sektor publik, swasta dan nonpemerintah, untuk menciptakan kondisi lebih baik bagi pertumbuhan ekonomi dan kesempatan kerja (dalam Nurzaman, 2002). Selanjutnya, International Labour Organization (2005) mendefinisikan proses partisipatif yang mendorong kemitraan antara dunia usaha dan pemerintah dan masyarakat 
pada wilayah tertentu yang memungkinkan kerjasama dalam perancangan dan pelaksanaan strategi pembangunan secara umum, dengan menggunakan sumber daya lokal dan keuntungan kompetitif dalam konteks global dengan tujuan akhir menciptakan lapangan pekerjaan yang layak dan merangsang kegiatan ekonomi.

Tujuan pengembangan ekonomi lokal adalah untuk mengembangkan ekonomi suatu wilayah yang berkelanjutan dengan mengoptimalkan pemanfaatan sumber daya lokal guna mempercepat pertumbuhan ekonomi wilayah, peningkatan kesejahteraan masyarakat, pengurangan kesenjangan antar kelompok masyarakat, antarsektor dan antarwilayah. Konsep yang sebagian besar menjadi dasar pengembangan ekonomi lokal adalah konsep Stamer (2004) yaitu konsep hexagonal pengembangan ekonomi lokal. Heksagonal pengembangan ekonomi lokal merupakan alat analisis yang dapat digunakan untuk menggambarkan dan mengukur kondisi pengembangan ekonomi lokal di suatu wilayah. Berdasarkan hasil pemetaan tersebut kemudian dilakukan analisis terhadap komponen heksagonal pengembangan ekonomi lokal yangberperan sebagai faktor pengungkit (leverage factor), yaitu faktor yang berpengaruh besar terhadap pengembangan ekonomi lokal.

Komponen pengembangan ekonomi lokal ada enam unsur yang disebut dengan heksagonal. Terdapat 6 (enam) segitiga yang secara keseluruhan membentuk heksagonal, yang berfungsi untuk mengorganisasikan konsep utama dan instrumen pengembangan ekonomi lokal. Heksagonal dapat membantu praktisi dan stakeholder untuk memahami kompleksitas pengembangan ekonomi lokal serta mempertimbangkan trade-off dan kemungkinan konflik yang ada dalam pengembangan ekonomi lokal. Heksagonal

\footnotetext{
${ }^{24}$ Direktorat Perkotaan dan Perdesaan. 2006. Panduan Revitalisasi Pengembangan Ekonomi Lokal. BAPPENAS.
}

pengembangan ekonomi lokal tersebut terdiri dari $^{24}$ :

1. Kelompok sasaran pengembangan ekonomi lokal.

Kelompok sasaran pengembangan ekonomi lokal adalah pelaku usaha yaitu pelaku usaha lokal, investor luar, dan pelaku usaha baru.

2. Faktor lokasi.

Faktor yang menggambarkan daya tarik dari sebuah lokasi bagi penyelenggaraan kegiatan usaha), terdiri dari: faktor lokasi terukur (tangible factor), faktor lokasi tidak terukur (intangible factor) bagi pelaku usaha dan faktor lokasi tidak terukur (intangible factor) individual.

3. Kesinergian dan fokus kebijakan.

Tiga hal yang saling berkaitan dalam pengembangan ekonomi lokal adalah perluasan ekonomi, pemberdayaan masyarakat dan pengembangan komunitas, serta pembangunan wilayah. Ketiga hal tersebut memiliki tujuan yang berbeda namun saling berhubungan dan membentuk keterkaitan.

4. Pembangunan berkelanjutan.

Terdiri dari pembangunan ekonomi, lingkungan, dan sosial. Aspek ini merupakan bagian dari pendekatan pengembangan ekonomi lokal yang inovatif.

5. Tata kepemerintahan.

Segitiga dalam ketatakepemerintahan memastikan bahwa hubungan pelaku usaha dan masyarakat dibangun atas berlangsungnya reformasi sektor 


\begin{tabular}{|c|c|c|c|c|}
\hline $\begin{array}{c}\text { Jurnal Penelitian \& } \\
\text { PPM }\end{array}$ & ISSN: 2442-448X & Vol 4, No: 2 & Hal: $129-389$ & Juli 2017 \\
\hline
\end{tabular}

publik dan pengembangan organisasi pelaku usaha.

6. Proses manajemen.

Pengembangan ekonomi lokal merupakan proses yang berkesinambungan yang terdiri dari diagnosa dan perencanaan, implementasi dan monitoring, serta evaluasi, patok duga (benchmark)dan refleksi.

\section{b. Pengembangan Masyarakat}

Pengembangan masyarakat adalah salah satu metode pekerjaan sosial yang tujuan utamanya untuk memperbaiki kualitas hidup masyarakat melalui pendayagunaan sumbersumber yang ada serta menekankan pada prinsip partisipasi sosial. Sebagai sebuah metode pekerjaan sosial, pengembangan masyarakat menunjuk pada interaksi aktif antara pekerja sosial dan masyarakat dimana mereka terlibat dalam setiap tahapannya.

Pengembangan masyarakat dapat didefinisikan sebagai metode yang memungkinkan orang dapat meningkatkan kualitas hidupnya serta mampu memperbesar pengaruhnya terhadap proses-proses yang mempengaruhi kehidupannya (AMA, 1993). Menurut Twelvetrees (1991:1) pengembangan masyarakat adalah "the process of assisting ordinary people to improve their own communities by undertaking collective actions." Definisi tersebut menyatakan bahwa pengembangan masyarakat merupakan "proses" membantu peningkatan kapasitas pada suatu masyarakat melalui tindakan kolektif.

Perserikatan Bangsa-bangsa telah memberikan kontribusi sehingga membuat community development sebagai suatu gerakan sosial dengan perhatian utama pada pembangunan desa-desa di negara Dunia Ketiga dan berkembang. Selanjutnya, gerakan sosial tersebut melakukan inisiasi dan memberikan dukungan pada community development dari perspektif internasional.

\author{
PBB mendefinisikan community \\ development (1960):
}

"community development is the processes by whichs the efforts of the people themselves are united with those of govermental authorities to improve the economic, social and conditions of communities, to integrade these communities into the life of the nations, and to enable them to contribute fully to national progress"

(dalam Nasdian, 2014: 31)

Istilah pengembangan masyarakat (community development) telah digunakan secara internasioanl dalam arti sebagai proses, yakni semua usaha swadaya masyarakat digabungkan dengan usaha-usaha pemerintah setempat guna meningkatkan kondisi masyarakat di bidang ekonomi, sosial, dan kultural serta untuk menggintegrasikan masyarakat yang ada ke dalam kehidupan berbangsa dan bernegara, dan memberi kesempatan yang memungkinkan masyarakat tersebut membantu secara penuh pada kemajuan dan kemakmuran bangsa (Conyers, 1996).

Wibawa, dkk (2010) menjelaskan pengembangan masyarakat sebagai sebuah proses yang diartikan sebagai suatu tindakan sosial yang mendorong masyarakat untuk:

1) Mengorganisasikan diri mereka sendiri untuk menyusun rencana dan melaksanakan tindakan bersama

2) Merumuskan kebutuhan-kebutuhan dan masalah-masalah bersama

3) Menyusun rencana kelompok dan individu untuk memenuhi kebutuhan dan memecahkan masalah sendiri

4) Melaksanakan rencana tersebut dengan sebanyak mungkin dengan mengandalkan sumber-sumber yang ada 
5) Menjangkau akses ke sumber-sumber di luar masyarakat baik dari badanbadan pemerintahan maupun swasta guna mendukung sumber-sumber yang ada.

Community development dapat dipahami sebagai kegiatan yang bertujuan untuk meningkatkan kondisi kehidupan masyarakat melalui keterlibatan masyarakat dan didasarkan kepada kekuatan yang dimiliki oleh warga masyarakat. Dalam pelaksanaannya, proses community development terdiri dari tahapan (Rothman, dkk, 1996):

\section{a. Assessment}

Assessment merupakan langkah awal yang dilakukan oleh peneliti dalam melakukan proses pengembangan masyarakat. Assessment dapat dikatakan sebagai proses terpenting yang harus ada dalam proses pengembangan masyarakat. Hasil dari assessment ini akan menentukan ketepatan serta efektivitas kegiatan pengembangan masyarakat itu sendiri. Dalam hal ini assessment dapat mencakup antara lain need assessment, identifikasi masalah, analisis masalah, dan resource assessment. Hal-hal yang berkaitan dengan assessment bukan hanya tentang masalah klien, melainkan juga sumbersumber, kekuatan-kekuatan, motivasi komponen-komponen fungsional, dan faktorfaktor yang positif lainnya yang dapat digunakan untuk mengatasi masalah klien dalam meningkatkan keberfungsian sosialnya.

\section{b. Plan of Treatment}

Plan of treatment merupakan sebuah proses insight dalam mengidentifikasi, memilah, menghubungkan masalah atau kebutuhan dnegan sumber-sumber yang dapat didayagunakan untuk memecahkan masalah atau memenuhi kebutuhan melalui serangkaian kegiatan (Wibawa, dkk: 2010). Rothman (1996:157) menjelaskan bahwa the planning processs in community organization has historically infolved citizen in decisions that affected them. Penjelasan ini meyakinkan bahwa sejak dulu masyarakat diikutsertakan dalam kegiatan planning karena keputusan apapun yang diambil akan mempengaruhi masyarakat. Dalam upaya mengatasi permasalahan yang ada, masyarakat diharapakan dapat memikirkan beberapa alternatif kegiatan yang dapat mereka lakukan. Alternatif kegiatan ini harus disesuaikan dengan permasalahan dan potensi yang ada di lingkungan mereka.

\section{c. Treatment}

Pada tahap ini dapat dilihat adanya implementasi dari strategi locality development, monitoring, dan evaluasi. Tahap ini memerlukan adanya perhitungan situasi yang akan menentukan tindakan yang diperlukan. Proses treatment (pelaksanaan) merupakan salah satu tahap yang paling penting dalam proses pengembangan masyarakat.Hal ini karena semua yang telah direncanakan dapat melenceng dalam pelaksanaannya di lapangan apabila tidak ada kerja sama diantara semua pihak. Rothman (1996:17) menjelaskan bahwa Implementasi dapat dijalankan ketika sistem tindakan dan target dapat bekerja sama secara kooperatif. Adanya persetujuan untuk perubahan dan alokasi sumberdaya yang diambil melalui pengambilan keputusan perlu untuk diimplementasikan.

Monitoring merupakan pemantauan secara terus-menerus pada proses pelaksanaan kegiatan. Monitoring dilakukan ketika kegiatan sedang berlangsung. Kegitan monitoring ini fokus mendeskripsikan apa yang terjadi saat kegiatan berlangsung. Monitoring dapat memberikan dua manfaat utama yaitu memberikan informasi untuk pegangan sementara program masih sedang berlangsung dan memberikan informasi bagi evaluasi berkala yang ditujukan baik kepada pelaksanaan program (proses dan hasil) ataupun kepada kerjasama diantara semua pelaku. Sementara itu, evaluasi dilakukan untuk mengidentifikasi apakah tujuan telah tercapai dan memutuskan adakah upaya yang harus dilakukan terkait perubahan yang terjadi 
karena tujuan telah tercapai. Dalam kegiatan pengembangan masyarakat, evaluasi dari hasil program terkadang tidak sesuai dengan yang telah direncanakan. Diharapkan dengan adanya evaluasi dapat memberikan umpan balik yang berguna bagi perbaikan suatu program ataupun kegiatan.

\section{d. Terminasi}

Terminasi merupakan tahap pengakhiran atau tahap pemutusan hubungan secara formal dengan masyarakat dengan masyarakat setempat sebagai sasaran program. Terminasi merupakan langkah penghentian sementara (sekuensi) kegiatan locality development, yang mungkin kelak akan ditindaklanjuti dengan rangkaian berikutnya.

\section{METODE}

Kajian ini menggunakan data sekunder yang didasarkan kepada studi dokumentasi dan pustaka. Studi dokumentasi lebih diarahkan untuk mengkaji dan menganalisis hasil laporan serta data yang telah dipublikasikan yang berkaitan dengan fenomena yang dikaji. Sementara itu studi pustaka lebih diarahkan untuk menganlisis fenomena yang ada didasarkan kepada konsep atau teori yang sesuai dengan fenomena yang dikaji

\section{Hasil Penelitian dan Pembahasan}

\section{Pengembangan Ekonomi Lokal}

Pengembangan yang dilakukan tentunya tidak terlepas dari pengembangan ekonomi local yang ada dalam masyarakat. Dalam penelitian ini, ekonomi local yang dikembangkan adalah tape yang ada sejak lama di Kabupaten Kuningan. Pengembangan tape di Kabupatenn Kuningan tentunya bertujuan agar jenis makanan ini berkembang tidak hanya di Kabupaten Kuningan saja tetapi juga mrambah ke daerah lain. Dengan demikian tape dari Kabupaten Kuningan ini menjadi produk unggulan. Selain itu, berkembangnya tape Kuningan ini sebagai produk unggulan juga dapat menyerap tenaga kerja serta menarik investor sehingga dapat membantu perkembangan ekonomi Kabupaten Kuningan secara keseluruhan. Penelitian dan pembahasan diarahkan kepada heksagonal dari pengembangan ekonomi local yang nantinya secara tidak langsung berhubungan dengan pengembangan masyarakat.

\section{a. Kelompok Sasaran}

Penamanan modal di Kuningan ditetapkan sebagai upaya meningkatkan petumbuhan ekonomi, menciptakan lapangan kerja baru dan mendukung petumbuhan ekonomi. Untuk itu, Pemerintah Kabupaten Kuningan mempunyai komitmen kuat untuk menciptakan iklim investasi yang kondusif sehingga dapat menarik investor untuk berinvestasi di Kuningan. Untuk mendukung iklim investasi yang baik, Pemerintah Kabupaten Kuningan telah menerapkan One Stop Service selama dua tahun yang didukung infrastruktur yang memadai (jalan, listrik, air, pasar) dan memiliki potensi sumber daya alam. Adapun produk unggulan Kuningan yaitu sirup jeruk nipis terdapat tiga unit usaha, dengan produksi \pm 70.000 botol/bulan berlokasi di Desa Ciawigebang. Tape Ketan 12 unit usaha dengan kapasitas produksi \pm 19 ton/bulan di Kec. Cibeureum dan Cigugur. Selain itu, terdapat Pasta Ubi Jalar, kapasitas 100 ton/bulan (PT Galih Estetika), Bawang Goreng jumlah unit usaha 25 unit dengan kapasitas produksi 500 ton/bulan di Kecamatan Kuningan, Cilimus, Ciawigebang dan Kalimanggis. Selanjutnya Nilam dan Cengkeh (minyak Atsiri) dengan kebutuhan produksi 5 ton/bulan, saat ini baru tersedia kapasitas produksi 2 ton/bulan. Selain itu ada juga produk Gemblong dan Opak Bakar.

Undang-Undang No. 32 tahun 2004 tentang Pemerintahan Daerah, memberikan peluang lebih luas kepada daerah untuk mengelola pembangunan wilayahnya. Peluang ini termasuk memacu pertumbuhan ekonomi melalui upaya-upaya strategis pada berbagai sektor ekonomi sesuai aturan yang berlaku. Salah satu kebijakan strategis pembangunan jangka panjang dalam RPJP (Rencana Pembangunan Jangka Panjang) Kabupaten Kuningan adalah peningkatan investasi, penyederhanaan proses dan prosedur 
perizinan, pelayanan pajak dan retribusi daerah. Penanaman modal menempati peran penting dan strategis untuk memacu laju pertumbuhan ekonomi (LPE) dan daya saing daerah, mengurangi angka kemiskinan dan pengangguran. Dalam rangka mencapai tujuan tersebut diperlukan langkah perencanaan pembangunan, khususnya dibidang penanaman modal melalui pelayanan yang kompetitif agar calon investor merasa lancar dan nyaman.

Pemerintah Daerah melalui BPPT (Badan Pelayanan Perizinan Terpadu) telah menggelar kegiatan sosialisasi pengisian LKPM yang dikhususkan bagi para pengusaha yang telah mendapat izin prinsip penamanan modal di Kabupaten Kuningan. Setiap penanam modal berkewajiban membuat laporan tentang kegiatan penanaman modal sesuai Undang-Undang No. 25 Tahun 2007. Laporan Kegiatan Penanaman Modal (LKPM) adalah laporan secara berkala mengenai perkembangan kegiatan perusahaan dan kendala yang dihadapi penanam modal. LKPM ditujukan untuk memantau realisasi investasi dan produksi. LKPM mencakup kegiatan penanaman modal yang dilakukan perusahaan di setiap lokasi dan bidang usaha investasi, kecuali bidang usaha perdagangan. Bagi perusahaan yang melakukan kegiatan penanaman modal di bidang usaha perdagangan, LKPM cukup berdasarkan lokasi yang telah dinyatakan pada Izin Prinsip. Berdasarkan LKPM pemerintah daerah nantinya dapat mengetahui perkembangan investasi di Kabupaten Kuningan

Investasi bagi penbusaha tape ketan di Kabupaten Kuningan ini juga menjadi kelompok sasaran bagi pengembangan ekonomi local Kabupaten Kuningan. Industry tape di Kuningan masih bersifat home industry. Hal ini menjadi salah satu kendala untuk pengembangan kea rah yang lebih besar lagi. Selian itu, produksi tape di Kabupaten Kuningan hanya ada di wilayah tertentu yaitu di Kecamatan Cibeureum, Kecamatan Sindangagung dan Kecamatan Cigugur. Berdasarkan data Dinas Koperasi dan UKM Kabupaten Kuningan, pada tahun 2013, home industry tape ketan paling banyak berada di kecamatan Cibeureum yang mana berjumlah 23 pengusaha tape ketan. Tape ketan di Desa Tarikolot, Kecamatan Cibeureum telah mampu memasarkan hasil produksinya tidak hanya di Jawa Barat, Jawa tengah, dan wilayah Jabodetabek, tetapi juga dapat mencapai wilayah lain di Pulau Jawa dan Sumatra bahkan berpeluang untuk diekspor ke mancanegara khususnya Malaysia dan Philipina. Kapasitas produksi perbulan di Desa Tarikolot mencapai 56.750kg (Dinas Perdagangan dan Perindustrian Kabupaten Kuningan, 2012)

\section{b. Faktor Lokasi}

Kabupaten Kuningan terletak di bagian timur Jawa Barat yang berada di lintasan jalan regional yang menghubungkan kota Cirebon dengan wilayah Priangan Timur dan sebagai jalan alternatif jalur tengah yang menghubungkan Bandung-Majalengka dengan Jawa Tengah. Letak Kuningan yang menjadi penghubung ini dimanfaatkan untuk pemasaran tape ketan untuk menjajkan barang hasil psoduksinya. Dengan demikian akan mudah ditemukan tape ketan khas Kuningan dijajakan sepanajang jalur transportasi tersebut.

\section{c. Keterkaitan dan Fokus Kebijakan}

Pelatihan kewirausahaan masyarakat telah dilaksanakan oleh Dinas Koperasi dan UKM Kabupaten Kuningan. Dari 21.334 UKM di Kuningan, baru 5.151 UKM yang telah mendapat binaan Pemerintah Kabupaten Kuningan. Ini berarti baru 5.151 UKM tersebut yang telah mendapat fasilitasi bantuan, baik berupa pelatihan, peralatan, mesin termasuk legalitas formal PIRT dan lain-lain. Promosi UKM akan terus dibantu, salah satunya melalui helatan UKM Expo. Seluruh UKM dengan berbagai produk unggulannya dipamerkan dalam acara tersebut. Digelarnya UKM Expo untuk yang pertama kalinya di Kabupaten Kuningan pada tahun 2015, mencerminkan adanyan keseriusan dari Pemerintah Daerah dalam memberikan pembinaan terhadap para pelaku usaha mikro 
dalam menggali, mengembangkan dan mengoptimalkan usahanya dalam menghadapi persaingan usaha yang semakin ketat. Pada UKM Expo, dihadirkan juga seluruh perbankan yang ada di Kuningan untuk menunjang para pengusaha yang membutuhkan modal. Maka, dengan begitu diharapkan akan terjadinya akad transaksi antara pelaku usaha dengan pihak perbankan untuk jangka panjang.

Secara spesifik belum ada kebijakan dari pemerintah Kabupaten Kuningan yang berkaitan dengan pengembangan tape sebagai produk unggulan Kabuoaten Kuningan. Kebijakan yang ada cenderung untuk semua UKM yang ada di Kabupaten Kuningan. Dengan demikian fasilitasi yang dilakukan oleh Pemerintah Kabupaten Kuningan mencakup untuk semua usaha yang ada di Kabupaten Kuningan.

\section{d. Pembangunan Berkelanjutan}

Pengembangan ekonomi lokal menjadi peran penting dan strategis untuk memacu laju pertumbuhan ekonomi (LPE) dan daya saing daerah, serta mengurangi angka kemiskinan dan pengangguran. Terkait usaha tape ketan sendiri, usaha ini telah memanfaatkan sumber daya manusia lokal sebagai tenaga kerja dan telah menjadi salah satu alternatif sumber pendapatan bagi masyarakat berpendidikan rendah terutama kaum perempuan. Motivasi, kegigihan, dan ketekunan pengusaha dalam mempertahankan usaha tape ketan cukup tinggi sehingga sebagian besar telah mampu mengakumulasikan modalnya.

Pengembangan usaha tape di Kabupaten Kuningan juga ditunjang dengan letak Kabupaten Kuningan yang berada di kaki Gunung Ciremai. Letak tersebut menjadikan Kabupaten Kuningan sebagai salah satu daerah tujuan wisata di Propinsi Jawa Barat. Sebagai daerah tujuan wisata Kabulaten Kuningan tentunya akan banyak dikunjungi oleh wisatawan. Hal ini sebagai nilai tambah dalam memasarkan tape sebagai produk unggulan sebagai buah tangan bagi para wisatawan.

\section{e. Tata Pemerintahan}

Untuk mengembangkan kemitraan antara pengusaha besar dnegan Usaha Mikro Kecil Menengah (UMKM) seperti usaha tape ketan, BPPT Kabupaten Kuningan telah mengadakan pengembangan kemitraan UMKM. Pengembangan UMKM ini untuk menjembatani atau memfasilitasi dan mengkomunikasikan berbagai kepentingan para pelaku usaha mikro, kecil, dan menengah melalui pengembangan kkerjasama atau kemitraan dengan pengusaha besar. Salah satunya dengan pengusaha Toserba yang ada di Kabupaten Kuningan

\section{f. Proses Mamajemen}

Bappeda Kuningan telah menggelar Saresehan Forum Pengembangan Ekonomi Daerah (FPED) bersama stakeholder terkait, seperti kelompok pengusaha UMKM, LSM, akademisi, dan SKPD terkait. Forum Pengembangan Ekonomi Daerah merupakan sebuah organisasi/ institusi formal maupun informal nonpemerintah yang terdiri dari beragam pemangku kepentingan (multistakehoder) di daerah yang memiliki tanggungjawab sosial dalam memfasilitasi, memotivasi maupun mendinamisir aktivitas ekonomi daerah dengan tujuan memberikan manfaat kepada masyarakat. Forum ini didesain sebagai media untuk pertukaran informasi, diskusi dan pengembangan berbagai macam program yang berhubungan dengan pengembangan ekonomi daerah dan regional. Dasar konsep ini tumbuh melalui semangat membangun ekonomi daerah melalui kerjasama antara masyarakat, pemerintah dan swasta, sehingga terjalin kemitraan yang seimbang.

Forum Pengembangan Ekonomi Daerah (FPED) diharapkan mampu mendorong pengembangan ekonomi masyarakat sesuai karakteristik daerah. Selain itu, diharapkan juga FPED ini akan membuka dialog yang mampu mendesain langkah-langkah ke depan. Misalnya, dapat memperbaiki peraturan, iklim usaha yang lebih kondusif, kemudahan permodalan, pengembangan manajemen, 
teknologi tepat guna, dan lain-lain serta langkah-langkah yang dapat diambil guna pengembangan ekonomi di Kabupaten Kuningan.

Stake holder yang dapat dilibatkan dalam usaha tape ketan Kuningan antara lain yaitu sebagai berikut:

a) Dinas Koperasi dan UKM sebagai wadah konsultansi, sistensi bisnis dan sarana penyalur aspirasi serta pemberdayaan bagi para pengusaha tape ketan.

b) Koperasi untuk meningkatkan fungsi simpan pinjam.

c) Dinas Perindustrian dan Perdagangan yang berperan untuk membantu dalam peningkatan pelatihan kewirausahaan, manajerial, teknik pemasaran dan keunggulan kompetitif serta inovasi produk tape.

d) Bekerja sama dengan pusat penelitian dan perguruan tinggi untuk memberikan penyuluhan pada petani terkait budidaya ketan.

\section{Pengembangan Ekonomi Lokal dan Sistem Dasar Pekerjaan Sosial}

Kegiatan pengembangan ekonomi lokal merupakan kegiatan perubahan yang dilakukan di masyarakat untuk memperbaiki kondisi dalam masyarakat itu sendiri seperti salah satunya yaitu untuk meningkatkan kesejahteraan masyarakat. Dalam melakukan perubahan tersebut, pekerja sosial harus memperhatikan empat sistem dasar pekerjaan sosial. Terkait dengan pengembangan usaha tape ketan, dapat dirumuskan sistem dasar pekerjaan sosial sebagai berikut:
a. Sistem Pelaksana Perubahan (change agent system)

Seorang pekerja sosial dapat disebut sebagai pelaksana perubahan (change agent), sementara itu lembaga-lembaga kesejahteraan sosial yang mempekerjakan disebut sebagai sistem pelaksana perubahan.

b. Sistem klien yaitu orang-orang yang memberikan kewenangan atau meminta pelayanan pekerja sosial, yang sudah menjadi penerima layanan yang mempunyai persetujuan kerja dengan pekerja sosial.Dalam hal ini sistem klien adalah Pemerintah Daerah Kabupaten Kuningan.

c. Sistem sasaran adalah pihak-pihak yang dapat dijadikan sasaran perubahan, atau dijadikan media yang dapat mempengaruhi proses pencapaian tujuan pertolongan. Dalam kegiatan ini sistem sasaran adalah masyarakat dimana masyarakat terebut akan diberdayakan.

d. Sistem kegiatan menunjuk pada orang-orang yang bekerjasama dengan pekerja sosial untuk melakukan usaha-usaha perubahan melalui pelaksaan tugas-tugas atau program kegiatan. Sistem kegiatan dalam kegiatan ini adalah stakeholder yang telah disebutkan di pembahasan sebelumnya.

\section{Penutup}

Tape ketan sebagai produk unggulan merupakan salah satu potensi yang dimiliki oleh Kabupaten Kuningan. Usaha tape ketan kini semakin meningkat dan menjadi usaha yang menyediakan lapangan kerja sekaligus peluang usaha. Melihat kesempatan atas potensi ini, usaha tape ketan di Kabupaten Kuningan dapat dijadikan sebagai salah satu kegiatan pembangunan yang didasarkan pada kapasitas lokal atau yang biasa disebut 


\begin{tabular}{|c|c|c|c|c|}
\hline $\begin{array}{c}\text { Jurnal Penelitian \& } \\
\text { PPM }\end{array}$ & ISSN: 2442-448X & Vol 4, No: 2 & Hal: $129-389$ & Juli 2017 \\
\hline
\end{tabular}

pengembangan ekonomi lokal. Pengembangan ekonomi lokal sendiri mendasari konsepnya pada pengembangan kewirausahaan lokal serta tumbuh kembangnya perusahaan-perusahaan lokal, kerja sama pemerintah lokal dengan swasta dan lembaga-lembaga lainnya dalam mengelola sumber-sumber yang potensial untuk mendorong aktivitas ekonomi. Dalam menganalisis usaha tape ketan sebagai pengembangan ekonomi lokal, dapat menggunakanheksagonal pengembangan ekonomi lokal yang berguna untuk menggambarkan dan mengukur kondisi usaha tape ketan sebagai pengembangan ekonomi lokal di wilayah Kabupaten Kuningan. Heksagonal pengembangan ekonomi lokal tersebut terdiri kelompok sasaran, faktor lokasi, keterkaitan dan fokus kebijakan, pembangunan berkelanjutan, tata kepemerintahan, dan proses manajemen. Berdasarkan kajian terlihat bahwa tape yang selama ini diklaim sebagai produk unggulan dari Kabupaten Kuningan belum diperhatikan secara khsuus oleh pemerintah. Hal ini terlihat dari kebijakan maupun kegiatan yang dilakuakn oleh pemerintah Kabuoaten Kuningan belum secara spesifik dilakukan untuk pengembangan tape. Semua kebijakn dan pengembangan ekonomi masih bersifat umum yang mencakup semua usaha yang ada di Kabupaten Kuningan.

Kabupaten Kuningan melalui pemerintah dan stakeholders yang tertarik untuk mngembangkan tape di Kuningan seharusnya sudah memfokuskan diri pada pengembangan tape sebagai produk unggulan. Hal ini dikarenakan dengan lebih focus untuk mengembangakna tape maka perkemabngan tape sebagai produk unggulan juga akan semakin besar. Hal ini tentunya akan mendukung pengembangan masyarakat dan peningkatan ekonomi masyarakat Kuningan secara keseluruhan.

\section{DAFTAR PUSTAKA}

Adi, Rukminto Isbandi. 2008. Intervensi Komunitas dan Pengembangan
Masayarakat: Sebagai Upaya Pemberdayaan Masyarakat. Jakarta: Rajawali Pers

AMA (1993), Local Authorities and Community Development: A Strategic Opportunity for the 1990s, London: Association of Metropolitan Authorities

Nasdian. 2014. Pengembangan Masyarakat. Jakarta (ID): Yayasan Obor Rakyat

Nurzaman, Siti Sutriah. 2002.Perencanaan Wilayah di Indonesia Pada Masa Sekitar Kritis. Penerbit ITB. Bandung.

Rothman, Jack. 1972. Three Models of Community Organization Practice, Illinois: Peacock Pers, Inc

Rubin, Herbert J, dan Irene S. Rubin. 1992. Community Organization and Development, 2nd edition, Newyork : Macmilan Publik

Twelvetrees, A. (1991), Community Work, London: McMillan

Wibawa, Budhi dkk. 2010. Dasar-Dasar Pekerjaan Sosial. Bandung: Widya Padjadjaran

Sumihardjo, Tumar. 2008. Daya Saing Berbasis Potensi Daerah. Fokusmedia, Bandung.

Direktorat Perkotaan dan Perdesaan. 2006. Panduan Revitalisasi Pengembangan Ekonomi Lokal. BAPPENAS.

http://www.radarcirebon.com/kuninganmiliki-21-334-ukm.html

http://kuninganterkini.com/index.php/ekonom i/4436-bppt-kembangkan-kemitraanukm-pengusaha.html

http://bppt.kuningankab.go.id/2016/09/05/kun ingan-ciptakan-iklim-investasi-yangkondusif/

https://identitasbangsa.wordpress.com/2010/1 0/12/investasi-minim-kuninganmulai-dilirik-investor/ 


\begin{tabular}{|c|c|c|c|c|}
\hline $\begin{array}{c}\text { Jurnal Penelitian \& } \\
\text { PPM }\end{array}$ & ISSN: 2442-448X & Vol 4, No: 2 & Hal: $129-389$ & Juli 2017 \\
\hline
\end{tabular}

http://www.neraca.co.id/article/2865/pelakuukm-se-kab-kuningan-ikutipelatihan-indigopreneur

http://bappeda.kuningankab.go.id/publikasidata/bidang-ekonomi/item/123bappeda-gelar-saresehan-forumpengembangan-ekonomi-daerahfped.html

http://dkukm.kuningankab.go.id/artikel/pelati han-kewirausahaan-melalui-gknbagi-masyarakat-petani http://dkukm.kuningankab.go.id/artikel/keme nkop-dan-ukm-dorong-ukmpasarkan-produknya-melalui-ecommerce

http://www.kuningankab.go.id/pemerintahan/ kecamatan/kecamatan-cibeureum

http://www.kuningankab.go.id/berita/dinaskoperasi-dan-ukm-gelar-ukm-expopertama-di-kabupaten-kuningan 